\title{
Textual Corrections and Emendations
}

For this edition corrections in the text of 1893 have been made at nine points: page 28 : line $8,42: 24,66: 23,94: 19$, I I $2: 8$, I $40: 6$, I $45: 26$, I $52: 8-9$, and I $80: 32$. These corrections are explained in the Textual Notes. An emendation has been made at xxi:g for reasons given in the Critical and Explanatory Notes. An emendation has not been made in the incomplete passage at $86: 27-28$, though one might seem required, and again an explanation is offered in the Critical and Explanatory Notes. A few minor corrections in punctuation, in the use of italics, and in accents in foreign words have been made without comment. 


\section{THE RENAISSANCE \\ STUDIES IN ART AND POETRY \\ ถบ}

WALTER PATER

fellow of arusamose college

SEVENTH THOUSAND

\section{MACMILLAN AND CO.}

LONDON AND NEW YORK

1893

All rigkts nesereat 


\section{The Renaissance}

STUDIES IN ART AND POETRY

THE 1893 TEXT 



\section{DEDICATION}

TO

C. L. S.

February, I 873 
Yet shall ye be as the wings of a dove 